\title{
CIAGLOŚĆ I ZMIANA WE WZORCACH MYŚLENIA STRATEGICZNEGO - WYNIKI BADAŃ
}

DOI: 10.33141/po.2020.07.01

\section{Janusz M. Lichtarski, Anna Witek-Crabb, Katarzyna Piórkowska, Rafał Trzaska, Maciej Wilczyński, Sylwia Wrona}

\section{Wprowadzenie}

A naliza indywidualnych uwarunkowań i procesów poprzedzających decyzje strategiczne, związanych $\mathrm{z}$ percepcją otoczenia i sposobem przetwarzania informacji jest jednym $\mathrm{z}$ nurtów badawczych szeroko eksplorowanych m.in. w obszarze zarządzania strategicznego (Adair, 2005; Finkelstein i in., 2009; Goldman i in., 2017). Ogół tychże uwarunkowań i procesów ujmowany jest w ramach myślenia strategicznego (strategic thinking), rozumianego jako proces poprzedzający planowanie strategiczne lub jako proces nadrzędny wobec planowania i formułowania strategii (Heracleous, 1998; Mintzberg, 1994). W odróżnieniu od planowania strategicznego, będącego $\mathrm{z}$ reguły procesem analitycznym, sekwencyjnym i szczegółowym, myślenie strategiczne najczęściej definiowane jest jako proces intuicyjny, twórczy i syntetyczny, ściśle związany z indywidualnymi predyspozycjami intelektualnymi najważniejszych decydentów w organizacji (Graetz, 2002; Liedtka, 1998).

To właśnie podmiot realizujący proces myślenia strategicznego, czyli strateg lub myśliciel strategiczny (strategic thinker), staje się kluczowym elementem tego procesu i zarazem interesującym obiektem badań. W warunkach zmienności i nieprzewidywalności, kiedy to ekstrapolacja i algorytmiczne postępowanie tracą na znaczeniu, to cechy indywidualne stratega, jego lub jej styl myślenia, sposób postrzegania rzeczywistości i podejmowania decyzji stanowią jeden $\mathrm{z}$ istotnych czynników wyróżniających organizację i budujących jej przewagę konkurencyjną. Od lat podejmowano więc próby identyfikacji cech charakteryzujących strategów, co doprowadziło do wypracowania pewnego zestawu tzw. cech wspólnych (Heracleous, 1998; Liedtka, 1998; Mintzberg, 1994; Porter, 2008).

Jednocześnie można zauważyć, że zdecydowanie mniejszą uwagę przywiązuje się do cech różnicujących strategów, a jak podkreślają A.K. Olson i B.K. Simerson (2015), pomiędzy myślicielami strategicznymi występują różnice nie tylko związane z cechami osobowości (które nie są przedmiotem badań autorów), ale również dotyczące całego sposobu myślenia strategicznego jako takiego - jego antecedencji, uwarunkowań, przebiegu, przejawów oraz rezultatów. Indywidualne cechy i styl myślenia stratega wpływają na typ wybieranej strategii, stosunek organizacji do niepewności czy podejście do konkurentów. Różne uwarunkowania branżowe - jak np. etap w cyklu życia sektora, koniunktura sektorowa lub dynamika wzrostu - wymagają także odmiennych cech i predyspozycji od stratega odpowiedzialnego za ukierunkowanie rozwoju przedsiębiorstwa.

W literaturze brak jest ogólnie przyjętej typologii myślicieli strategicznych, pomimo podejmowania prób jej opracowania (Horvath, 2009; Olson, Simerson, 2015), co pozwala zidentyfikować ważną i interesującą lukę badawczą. Wydaje się to niezwykle obiecujący kierunek badań nie tylko $\mathrm{w}$ kontekście wyjaśniania różnic $\mathrm{w}$ formułowanych i przyjmowanych strategiach organizacji, ale także ze względu na walory aplikacyjne takiego rozwiązania, np. możliwości wykorzystania przy obsadzaniu stanowisk w organach kolegialnych o charakterze decyzyjnym, nadzorującym lub wspomagającym, mających istotny wpływ na strategię organizacji, jak np. zarządy, rady nadzorcze, zespoły doradcze czy komisje ds. strategii. Zrozumienie cech różnicujących strategów, a w dalszym etapie - wyjaśnienie, w jaki sposób te różnice mogą wpływać na podejmowanie decyzji strategicznych w różnych warunkach sektorowych, stanowiło istotny motyw podjęcia badań. Jednym $\mathrm{z}$ kryteriów różnicujących strategów jest podejście do zmian i poziom akceptacji niepewności, prowadzące do opowiadania się bardziej za ciągłością lub za zmianą w decyzjach strategicznych.

Celem niniejszego artykułu jest opracowanie zestawienia charakterystycznych przejawów myślenia strategicznego zorientowanego na zmianę lub na ciągłość na podstawie przeprowadzonych badań terenowych. Analizowane podejście do zmian to jeden z sześciu wymiarów różnicujących strategów, wyłonionych przez autorów na podstawie studiów literatury. W części teoretycznej niniejszego opracowania wykorzystaną metodą badawczą jest systematyczno-krytyczny przegląd literatury (Czakon, 2011; Linnenluecke i in., 2020), z kolei w prezentowanych badaniach empirycznych zastosowano podejście jakościowe, wykorzystując częściowo ustrukturyzowane indywidualne wywiady pogłębione (IDI, $\mathrm{n}=18)^{1}$.

Układ artykułu jest następujący. W pierwszej sekcji przybliżone zostały podstawy teoretyczne dotyczące zarówno konstruktu, jakim jest myślenie strategiczne, jak i identyfikacji cech wspólnych i różnicujących strategów 
ze szczególnym uwzględnieniem podejścia do zmiany i akceptacji niepewności. W kolejnej sekcji został przedstawiony opis projektu badań, w tym wykorzystanych metod i technik badawczych. W następnych sekcjach zaprezentowane i przedyskutowane zostały wyniki badań biograficznych i terenowych. W ostatniej części artykułu ujęto główne wnioski wynikające $\mathrm{z}$ przeprowadzonych analiz, a także wskazano na ograniczenia prowadzonych badań, dalsze pola eksploracji i kierunki badań w ramach poruszanej problematyki.

\section{Podstawy teoretyczne}

\section{Myślenie strategiczne i stratedzy}

M yślenie strategiczne (strategic thinking) zakorzenione jest w różnych dyscyplinach i teoriach, jednak swoje główne semantyczne i poznawcze odzwierciedlenie znajduje w zarządzaniu strategicznym (Amitabh, Sahay, 2007). Koncepcja myślenia strategicznego przejawia się w poszukiwaniu przyszłych kierunków i sposobów działania organizacji oraz w zróżnicowanych indywidualnych postawach mogących prowadzić do określania i redefiniowania strategii przedsiębiorstwa (Goldman $\mathrm{i}$ in., 2015; Haycock i in., 2012).

W literaturze dominują dwa podstawowe nurty badawcze myślenia strategicznego. W pierwszym nurcie, tzw. Mintzbergowskim, badacze zwracają uwagę przede wszystkim na kreatywno-intuicyjny charakter myślenia strategicznego i postrzegają zarządzanie strategiczne w kategoriach procesowych, w drugim zaś, tzw. Porterowskim, podkreślane są aspekty zbierania danych i stosowania narzędzi analitycznych (analiz strategicznych), a ujęcie strategii ma charakter pozycyjny (Heracleous, 1998), czego efektem jest koncentracja w głównej mierze na strategiach konkurencyjnych.

Nowsze konceptualizacje myślenia strategicznego bazują na połączeniu intuicji i kreatywności stratega $\mathrm{z}$ analizą i przetwarzaniem danych w celu integracji jego działań i rozwiązywania złożonych problemów. Intuicyjne i kreatywne zachowania myśliciela strategicznego prowadzą do bardziej efektywnych działań, nie tylko na poziomie indywidulanym, ale również organizacyjnym poprzez przyczynianie się do poprawy szeroko rozumianych dokonań przedsiębiorstwa (Murithi i in., 2018).

Myślenie strategiczne jako poznawcza koncepcja eksplorowana w zarządzaniu strategicznym kieruje także uwagę na postać stratega/myśliciela strategicznego (strategic thinker $)^{2}$ wraz z cechami wyróżniającymi tę grupę decydentów (tzw. cechami wspólnymi strategów), jak również cechami różnicującymi ją wewnętrznie. Myśliciel strategiczny (strategic thinker), określany w artykule zamiennie jako strateg, jest najczęściej identyfikowany jako jednostka zajmująca naczelną pozycję i podejmująca kluczowe decyzje w przedsiębiorstwie (Eisenhardt, 1990 , s. 39-54), ponosząca odpowiedzialność za całokształt zarządzania organizacją (Steptoe-Warren i in., 2011, s. 238-239) oraz charakteryzująca się wysokim poziomem refleksji nad własnymi decyzjami i działaniami (Dhir i in., 2018, s. 274).

\section{Cechy wspólne i cechy różnicujące strategów}

Bazując na rezultatach studiów literatury, myśliciela strategicznego można odróżnić od innych decydentów w organizacji na podstawie dwóch kryteriów, tj. przyjmowanej perspektywy oraz stosowanego stylu myślenia.

Strateg definiowany jest jako jednostka przyjmująca długookresową perspektywę strategiczną, w odróżnieniu od krótkookresowej perspektywy operacyjnej, a także charakteryzująca się refleksyjnym stylem myślenia.

Najważniejsze przejawy perspektywy strategicznej to:

a) długookresowy horyzont czasowy myślenia o rozwoju i funkcjonowaniu organizacji (Hanford, 1995; Liedtka, 1998),

b) całościowe widzenie przedsiębiorstwa w otoczeniu,

c) wizjonerskie podejście do postrzegania i tworzenia rzeczywistości (Hamel, Prahalad, 1993; Heracleous, 1998).

Drugim kryterium, które odróżnia strategów od niestrategów, jest refleksyjny styl myślenia, opierający się na świadomości i głębszej refleksji (Dhir i in., 2018), a także na zdolności uczenia się (Liedtka, 1998). Strateg myśli i podejmuje decyzje w sposób świadomy, w oparciu o refleksję zarówno nad swoimi wcześniejszymi decyzjami, jak i nad samym procesem rozumowania, którego jest podmiotem. Tym sposobem nieustannie się uczy i podejmuje decyzje w sposób celowy, nieprzypadkowy i na bazie oglądu sytuacji.

W przypadku myślicieli strategicznych można mówić o procesie uczenia się na zasadzie podwójnej pętli, w którym charakterystyczne jest podważanie dotychczasowych założeń i przekonań, aby wypracowywać nowe rozwiązania (Heracleous, 1998). Jak trafnie zauważa J.M. Liedtka (1998), myśliciel strategiczny to bardziej ktoś, kto się systematycznie uczy, niż ktoś, kto wie.

Jednocześnie, obok przywołanych cech wspólnych charakteryzujących strategów, występują pomiędzy nimi wyraźnie obserwowalne różnice. Mają one swoje odzwierciedlenie zarówno $\mathrm{w}$ decyzjach związanych $\mathrm{z}$ kierunkami rozwoju i strategią organizacji, jak i w przebiegu procesu myślenia strategicznego i formułowania strategii.

Zidentyfikowane na podstawie systematyczno-krytycznego przeglądu literatury wymiary/cechy różnicujące strategów można uporządkować w dwóch grupach.

Pierwszą grupę stanowią wymiary związane z przedmiotem myślenia strategicznego (treścią), m.in. takie jak:

a) podejście do zmian i akceptacja niepewności (Godet, 2010; Hamel, Prahalad, 1993; Johnson, 2007; Liedtka, 1998; Olson, Simerson, 2015; Sushil, 2012),

b) postrzeganie otoczenia w perspektywie jego wrogości/ przyjazności i podejście do innych aktorów (Crouch, 1998; Horowitz, 2014),

c) przetwarzanie informacji i sposób podejmowania decyzji (Eisenhardt, 1990; Goldman i in., 2017; Heracleous, 1998; Hodgkinson, Sparrow, 2002; Steptoe-Warren $\mathrm{i}$ in., 2011),

d) punkt odniesienia i sposób wykorzystania danych (Heracleous, 1998; Mintzberg, 1994). 
Drugą grupę stanowią wymiary/cechy związane z samym przebiegiem procesu myślenia strategicznego, tj.:

a) zespołowość procesu myślenia strategicznego (Bonn, 2005; Goldman i in. 2015; Johnson, 2007; Olson, Simerson, 2015),

b) celowość i planowość procesu myślenia strategicznego (Mintzberg, 1994; Olson, Simerson, 2015).

W niniejszym opracowaniu uwaga autorów skupiona została wyłącznie na pierwszym spośród zidentyfikowanych wymiarów różnicujących strategów, a mianowicie na podejściu do zmian i akceptacji niepewności otoczenia. Powodem koncentracji autorów na pierwszym z wymiarów jest po pierwsze fakt, że w świetle wyników przeprowadzonych badań jakościowych okazał się on istotnie różnicujący wzorce myślenia strategicznego. Po drugie zaś ograniczone ramy objętościowe opracowania uniemożliwiają prezentację wyników dotyczących pozostałych wymiarów na podobnym poziomie szczegółowości. Wymiar ten wraz z wartościami, jakie może przyjmować, i jej przejawami został szerzej scharakteryzowany w kolejnej sekcji.

\section{Ciągłość i zmiana jako cecha różnicująca}

Podejście do rozwoju i wprowadzania zmian (continuity vs change, exploitation vs exploration) to jeden $\mathrm{z}$ wymiarów wykorzystywanych do różnicowania wielu zjawisk w naukach o zarządzaniu (Siren i in., 2012), zarówno na poziomie organizacyjnym (Raisch, Birkinshaw, 2008), jak i indywidualnym (Bonesso i in., 2014). Stosowany jest również jako różnicujący wzorce myślenia strategicznego i myślicieli strategicznych (Godet, 2010; Hamel, Prahalad, 1993; Johnson, 2007; Liedtka, 1998; Olson, Simerson, 2015; Sushil, 2012).

W odniesieniu do myślenia strategicznego podział ten nie ma charakteru dychotomicznego, może przybierać wartości określone na kontinuum pomiędzy wierzchołkami (Olson, Simerson, 2015) lub być traktowany w kategoriach tzw. oburęczności (ambidexterity) (Bonesso i in., 2014; Lubatkin i in., 2006; Sage i in., 2010; Sushil, 2012).

Orientacja na kontynuację i poszukiwanie korzyści (exploitaition, advantage-seeking) przejawia się w zachowawczym myśleniu o rozwoju organizacji i związana jest z niskim poziomem akceptacji niepewności otoczenia. Osoba reprezentująca taki sposób myślenia strategicznego zazwyczaj formułuje zachowawcze wizje i koncentruje się na utrzymaniu obecnego stanu, ostrożnie planuje stopniowy rozwój na bazie prognoz dotyczących otoczenia (Benner, Tushman, 2003; Lubatkin i in., 2006). Skupia się przede wszystkim na rozwijaniu i doskonaleniu obecnych produktów i technologii oraz zwiększeniu satysfakcji dotychczasowych klientów organizacji (Benner, Tushman, 2003; He, Wong, 2004; Hitt i in., 2011; Lubatkin i in., 2006). W swoich planach skupia się na zwiększaniu efektywności posiadanych zasobów i w dużym stopniu uwzględnia istniejące ograniczenia zasobowe, czego efektem są strategie typu fit. Exploitera cechuje niska akceptacja niepewności i popełniania błędów, unikanie ryzyka i redukowanie niepewności przez stosowanie sprawdzonych rozwiązań lub kopiowanie strategii innych podmiotów (Lubatkin i in., 2006). Duża niepewność otoczenia powoduje u niego dyskomfort. Znacznie lepiej czuje się on w uporządkowanej i przewidywalnej rzeczywistości.

Z kolei orientacja na zmianę (exploration, opportunity-seeking) przejawia się poszukiwaniem okazji, dążeniem do szybkiego rozwoju i wprowadzaniem radykalnych zmian (Hitt i in., 2011). Osoba przejawiająca ten styl myślenia strategicznego formułuje odważne wizje rozwoju i preferuje przełomowe rozwiązania (Lubatkin i in., 2006). Chętnie wprowadza nowe produkty i wchodzi na nowe, niesprawdzone rynki (Hitt i in., 2011, Ireland i in., 2003). Poszukuje kreatywnych sposobów dotarcia do nowych grup odbiorców i zaspokojenia potrzeb klientów (Benner, Tushman, 2003). Explorer koncentruje się na innowacyjności, akceptuje wysoki poziom ryzyka i możliwość popełniania błędów (Lubatkin i in., 2006; March, 1991). Jest otwarty na poszukiwanie nowych umiejętności i szybkie uczenie się (Bonesso i in., 2014; Brown, Eisenhardt, 1997), a w swoich zamierzeniach nie ogranicza się do posiadanych zasobów, czego rezultatem są strategie typu stretch. Dobrze czuje się w warunkach dynamicznych zmian i szybkiego rozwoju, a stagnacja może prowadzić w tym przypadku do frustracji i znużenia jednostki.

W części empirycznej niniejszego opracowania przedstawione zostały przejawy scharakteryzowanych wcześniej orientacji myślicieli strategicznych, identyfikowane w ramach własnych badań terenowych, na poziomie opisów konkretnych działań, podejmowanych decyzji oraz opinii i odczuć respondentów. Identyfikacja przejawów orientacji na kontynuację i zmianę w badaniach jakościowych pozwala na ilustrację poszczególnych wzorców myślenia strategicznego za pomocą konkretnych cytatów oraz na identyfikację potencjalnych uwarunkowań kontekstowych poszczególnych cech na poziomach: indywidualnym, organizacyjnym i środowiskowym. Dodatkowo, pochodzące $z$ badań cytaty stanowić będą podstawę i wsparcie w procesie opracowania kwestionariusza ankiety do planowanych badań ilościowych.

\section{Metoda badawcza}

$\mathbf{P}$ ostępowanie badawcze w projekcie „Typy strategów identyfikacja typów strategów i sposobów myślenia strategicznego" jest wieloetapowe i obejmuje m.in. analizę piśmiennictwa $\mathrm{z}$ wykorzystaniem systematyczno-krytycznego przeglądu literatury oraz badania terenowe $\mathrm{z}$ wykorzystaniem częściowo ustrukturyzowanych wywiadów pogłębionych (IDI) ${ }^{3}$.

$\mathrm{W}$ analizie piśmiennictwa $\mathrm{z}$ zastosowaniem systematyczno-krytycznego przeglądu literatury wykorzystano bazę Scopus, obejmującą najważniejsze czasopisma z zakresu zarządzania strategicznego. Zakres poszukiwań zdefiniowano hasłami „strategic thinking” oraz „strategic thinkers" występującymi w tytule, abstrakcie i słowach kluczowych. W rezultacie przeszukiwań uzyskano 1296 publikacji (na dzień 12.06.2019). Po nałożeniu kryteriów ograniczających, m.in. recenzowane publikacje, język angielski, 
obszar „Business, Management \& Accounting”, do analizy abstraktów wyłoniono 146 tekstów z pełnym dostępem. Po analizie abstraktów, na podstawie sprawdzenia merytorycznego powiązania artykułu z badanymi przez autorów obszarami stylów myślenia strategicznego i cech strategów, do dalszej analizy zakwalifikowano 56 publikacji. Dodatkowych 8 publikacji dołączono do analizy na podstawie tzw. kuli śnieżnej (publikacje z referencji). Ostatecznie analiza pełnych tekstów objęła swoim zakresem 64 publikacje z lat 1998-2018, w tym odpowiednio: artykuły teoretyczne i koncepcyjne - 20; z wynikami badań jakościowych - 16; teksty przeglądowe - 10 artykułów; z wynikami badań ilościowych - 9; inne - 9 artykułów). Celem analizy literatury było zapoznanie się z wynikami badań zbliżonych, umieszczenie projektu w szerszym kontekście, stworzenie ram konceptualnych dla badań empirycznych oraz dostarczenie wzorca, do którego będzie można odnieść wyniki uzyskane $\mathrm{w}$ badaniach terenowych.

W badaniach terenowych wykorzystano częściowo ustrukturyzowane indywidualne wywiady pogłębione $(\mathrm{IDI})^{4}$, przeprowadzone na próbie 18 celowo dobranych respondentów. Respondenci zaproszeni do udziału w badaniu spełniali następujące kryteria inkluzji: 1) właściciele przedsiębiorstw lub przedstawiciele naczelnego kierownictwa (prezes zarządu, dyrektor naczelny, dyrektor ds. rozwoju itd.); 2) mający co najmniej 5-letnie doświadczenie na stanowisku w danej organizacji; 3) reprezentujący dynamicznie rozwijające się przedsiębiorstwa ${ }^{5} \mathrm{w}$ różnych branżach. $\mathrm{Z}$ badań wyłączono zarówno mikroprzedsiębiorstwa, jak i podmioty zależne $\mathrm{z}$ niskim poziomem autonomii $\mathrm{w}$ zakresie opracowania i wdrażania strategii (spółki-córki, oddziały i filie zagranicznych korporacji, spółki Skarbu Państwa). Tabela 1 przedstawia syntetyczną charakterystykę respondentów biorących udział w badaniu oraz reprezentowanych przez nich organizacji. Wywiady zrealizowano w okresie listopad 2019 - styczeń 2020. Ich przeprowadzenie zlecono agencji specjalizującej się w prowadzeniu tego typu badań. Średni czas trwania wywiadu to 90 minut.
Celem badań terenowych była identyfikacja nastawienia (mindset) i stylów myślenia strategicznego - w tym m.in. dotyczących podejścia do zmian i akceptacji niepewności otoczenia - poprzez pogłębioną analizę opisywanych przez respondentów zdarzeń, decyzji i ich opinii na temat procesu formułowania strategii, uwarunkowań, efektów itd. Wywiady były nagrywane i transkrybowane, a następnie poddawane kodowaniu i analizie $\mathrm{w}$ wieloetapowym procesie zgodnie $\mathrm{z}$ rekomendacjami odnoszącymi się do projektowania i realizacji badań o charakterze jakościowym (Creswell, Zhang, 2009).

\section{Wyniki badań}

W trakcie badań terenowych przeprowadzonych na 18 osobach spełniających kryteria myślicieli strategicznych zidentyfikowano wzorce myślenia strategicznego, wskazujące na dominację zarówno orientacji na kontynuację i poszukiwanie korzyści (exploitation), jak i orientacji na zmianę i poszukiwanie okazji (exploration).

Jakościowa analiza wywiadów została przeprowadzona dla każdego respondenta niezależnie przez czterech badaczy w celu identyfikacji dominujących cech i profilowania myślicieli strategicznych. Przyjmując wynik zgodności badaczy na poziomie co najmniej 0,75 pkt., w przypadku 9 badanych za dominującą orientację uznano orientację na kontynuację, zaś w przypadku 7 respondentów jako dominującą uznano orientację na zmiany. Warto podkreślić, że w przypadku 5 spośród analizowanych przypadków stwierdzono wyraźnie obserwowalne jednoczesne przejawy obu orientacji ( $w$ różnych proporcjach i ze wskazaniem na dominującą, jednak obie $\mathrm{z}$ dużym natężeniem), co może stanowić potwierdzenie oburęczności (ambidexterity) w podejściu do zmian myślicieli strategicznych. W przypadku dwóch badanych nie zidentyfikowano wyraźnych przejawów żadnej z orientacji, co może wynikać z nieostrej sylwetki respondenta bądź z niewystarczających informacji na temat podejścia do zmian i akceptacji niepewności otoczenia ujętych w wywiadzie.

Tabela 1. Charakterystyka respondentów i organizacji

\begin{tabular}{|c|c|c|c|c|c|c|c|}
\hline Nr resp. & Płeć & $\begin{array}{c}\text { Wielkość } \\
\text { organizacji }\end{array}$ & Branża & Nr resp. & Płeć & $\begin{array}{c}\text { Wielkość } \\
\text { organizacji }\end{array}$ & Branża \\
\hline 1 & M & $10-49$ & motoryzacyjna & 10 & K & $50-250$ & gastronomiczna \\
\hline 2 & K & $50-250$ & nieruchomości & 11 & K & $50-250$ & chemiczna \\
\hline 3 & M & $50-250$ & budownictwo & 12 & M & pow. 250 & bezpieczeństwo \\
\hline 4 & M & $10-49$ & IT & 13 & M & $10-49$ & elektroniczna \\
\hline 5 & K & $50-250$ & usługi HR & 14 & M & pow. 250 & medyczna \\
\hline 6 & M & pow. 250 & spożywcza & 15 & M & $50-250$ & farmaceutyczna \\
\hline 7 & M & $10-49$ & edukacyjna & 16 & M & $10-49$ & nieruchomości \\
\hline 8 & M & $50-250$ & finanse & 17 & M & pow. 250 & medyczna \\
\hline 9 & M & $10-49$ & gastronomiczna & 18 & M & $10-49$ & elektroniczna \\
\hline
\end{tabular}

Źródło: opracowanie własne 
Tabela 2. Orientacje na kontynuację i zmianę w myśleniu strategicznym ${ }^{7}$

\begin{tabular}{|c|c|c|}
\hline & Exploitation / kontynuacja & Exploration / zmiana \\
\hline Obszar / kryterium & \multicolumn{2}{|c|}{ Badania terenowe (id respondenta, wiersz) } \\
\hline $\begin{array}{l}\text { Charakter wizji, szybkość rozwoju, } \\
\text { poszukiwanie przewagi } \\
\text { (Lubatkin i in., 2006; March, 1991; } \\
\text { Schumpeter, 1934; Holland 1975; } \\
\text { Kuran, 1988) }\end{array}$ & $\begin{array}{l}\text { „Wydaje mi się, że taki ostrożny rozwój. Taka jest } \\
\text { nasza polityka (...). Ostrożny dlatego, by nie wpaść } \\
\text { w pułapkę nowych zobowiązań” (7, 77). } \\
\text { „Ta strategia jedzenia mała tyżeczka na pewno się } \\
\text { sprawdza” (12, 596). „Przede wszystkim stabilny } \\
\text { rozwój. To jest podstawa do tego, żeby nie tworzyć } \\
\text { jakichś gwiazd, które szybko, mocno płoną, a potem } \\
\text { gasna i spadaja” (18, 463) (o planach dotyczących } \\
\text { rozwoju - przyp. aut.) } \\
\text { „Mamy dość dużą stałość. Interesuje nas wzrost, } \\
\text { wzrost obrotów i udziału rynkowego i strategię } \\
\text { realizujemy w taki dość stabilny, nie za szybki, } \\
\text { sposób” (3, 352) } \\
\text { „My musimy uporządkować strukturę w taki sposób, } \\
\text { by w razie silnego spadku, by ta struktura dała } \\
\text { nam szansę, by przetrwać. To nasz podstawowy cel. } \\
\text { Porządkujemy nasz biznes. My już nie będziemy się } \\
\text { aż tak silnie rozwijać, a raczej optymalizować to, co } \\
\text { mamy” (14, 660) }\end{array}$ & $\begin{array}{l}\text { „Nie bójmy się eksperymentować, nie bójmy się być } \\
\text { wizjonerami. Takie clue tego jak tworzyć strategię } \\
\text { - mieć wizję czegoś, (...), a potem wymyślić, jak to } \\
\text { zrobić” (1, 917) } \\
\text { „Przewidywalni są tylko ci, którzy tłuka jedno i to } \\
\text { samo” (2, 283) } \\
\text { „Firma bardzo dużo inwestuje w rozwój, w swoje } \\
\text { produkty. Gdzieś ponad } 10 \text { procent obrotu firma } \\
\text { inwestuje w tak czy inaczej rozumiane badania } \\
\text { i rozwój, to jest duzo” (17, 155) } \\
\text { „Strategię opieram na moich wizjach. Staram się być } \\
\text { wizjonerem i nadawać kurs pewnym sprawom” } \\
\text { (4, 194) } \\
\text { "Cały czas będę powtarzał, że potrzebny jest } \\
\text { otwarty umyst, takie nawet bym powiedział } \\
\text { beztroskie spogladanie, takie wizjonerstwo, bo to } \\
\text { tego potrzeba przy tworzeniu strategii” (1, 899) }\end{array}$ \\
\hline $\begin{array}{l}\text { Tempo zmian i mechanizm } \\
\text { odpowiedzi (adaptacja vs innowacja) } \\
\text { (Lubatkin i in., 2006) }\end{array}$ & $\begin{array}{l}\text { „U nas nie ma zmian diametralnych zmian (...) to } \\
\text { bardziej się opiera na np. zoptymalizowaliśmy nasze } \\
\text { produkty, braliśmy pod uwagę ich rentownośćc } \\
(15,267) \\
\text { „My tylko się dostosowujemy do rynku. } \\
\text { Aktualizujemy” (12, 449) } \\
\text { „Ogólna strategia nie została przez te } 15 \text { lat } \\
\text { zmieniona. Oczywiście dopasowujemy działania } \\
\text { i narzędzie. Reagujemy na otoczenie rynkowe, ale } \\
\text { strategia nie została zmieniona” (14, 239) } \\
\text { „W zasadzie podoba mi się to, że jesteśmy } \\
\text { przygotowani na to, co nastęuje. Nasz pomysł } \\
\text { przewidywania różnych scenariuszy się sprawdził. } \\
\text { Nic nas nie zaskoczyło” (16, 371) }\end{array}$ & $\begin{array}{l}\text { „Z dnia na dzień zmiana strategii, taktyki. Trzeba } \\
\text { cały czas być takim zwinnym a nie być takim } \\
\text { „zastałkiem” i nie iść w tym samym kierunku, tylko } \\
\text { ustalić, czy to, co się ustaliło i czy to jest adekwatne. } \\
\text { Bardzo często firmy są tak skupione na tym, co } \\
\text { chca zrobić, że nie bardzo widza to, co się zmieniło } \\
\text { w międzyczasie” }(6,52) \\
\text { „Sa jakieś warunki, sa jakieś przeszkody i po prostu } \\
\text { z tymi przeszkodami trzeba sobie poradzić. (...) } \\
\text { Mi się też wydaje, że to jest dość twórcze zadanie, } \\
\text { bo trzeba wymyślić coś czego nie ma albo połaczyć } \\
\text { znane elementy waką́ nieoczekiwana całośc” } \\
\text { (10, 850) } \\
\text { „Przede wszystkim zmiana i informacje. Zmiana } \\
\text { związana ze wszystkim. To musi być permanentna } \\
\text { zmiana. Jeśli się na nia nie nastawiamy, to } \\
\text { w pewnym momencie odpadniemy z rynku” } \\
\text { (16, 46) }\end{array}$ \\
\hline $\begin{array}{l}\text { Rynek / klient } \\
\text { (Benner, Tushman, 2003; } \\
\text { Lubatkin i in., 2006) }\end{array}$ & $\begin{array}{l}\text { „Na nowe rynki i na zagranice trzeba mieć } \\
\text { pieniądze” }(18,467) \text { (o wchodzeniu na nowe rynki } \\
\text { - przyp. aut.) } \\
\text { „(..) dostosowanie się do klienta, to jest ważne. } \\
\text { Z każdym klientem inaczej się współpracuje, inaczej } \\
\text { rozmowy wyglądają" (11, 93) } \\
\text { „Największy rozwój już mieliśmy, a teraz trzeba } \\
\text { się skupić na minimalizowaniu błędów, które } \\
\text { popetniamy i na rozwoju rynków, które już mamy } \\
\text { opanowane” (12, 383) } \\
\text { „Weryfikacja czy rynek chce nas w tej formie, } \\
\text { w której jesteśmy czy chce nas w innej formie (...)” } \\
\text { (10, 1205) (o planach rozwoju rynku - przyp. aut.) }\end{array}$ & $\begin{array}{l}\text { „To jest związane nie tylko ze sprzedaża produktu, } \\
\text { ale z kreowaniem. My ten rynek kreujemy. (...) } \\
\text { Mamy najbogatsze portfolio, jeśli chodzi o marki } \\
\text { własne na świecie” (14, 18) } \\
\text { „Nowi klienci non stop przychodza, z różnych branż } \\
\text { przychodza, zamawiają różne szkolenia. To się } \\
\text { rozwija. My jesteśmy otwarci na potrzeby naszych } \\
\text { klientów (...) To klient chce, żebyśmy na nowe rynki } \\
\text { wchodzili” (5, 801) } \\
\text { „Otwieramy nowe gałęzie w naszym } \\
\text { przedsiębiorstwie” (8, 143) } \\
\text { „My sami kreujemy potrzeby klienta, a nie } \\
\text { odpowiadamy na potrzeby klienta” }(14,571)\end{array}$ \\
\hline $\begin{array}{l}\text { Produkty / technologia/ innowacje } \\
\text { (He, Wong, 2004; Nonaka, 1994) }\end{array}$ & $\begin{array}{l}\text { „Odpowiedzialność jest najważniejsza rzecza. Jeżeli } \\
\text { by nie było dywersyfikacji portfela ustug (..), wtedy } \\
\text { jest jeszcze bardziej ryzykownie” }(4,314) \\
\text { „Z innowacyjnościa produktu też za bardzo nie } \\
\text { można szaleć (...)” (11, 93) } \\
\text { „Koła nie wymyśliliśmy. To jest myśl techniczna } \\
\text { oparta na tych materiałach, które są" }(18,60) \\
\text { „Ograniczamy się do rzeczy, którymi się zajmujemy. } \\
\text { (...) My się na tym znamy }(. . .) ”(13,392)\end{array}$ & $\begin{array}{l}\text { „To taki mój dodatni wpływ, bo ja jestem taka } \\
\text { osobą, która kreuje nowe rozwiązania i mam takie } \\
\text { wrażenie, że rzadko mnie ta intuicja myli” }(14,391) \\
\text { „Każdy pomyst, który usiłowaliśmy wcielić w życie } \\
\text { i czy on wyszedt, czy nie, to ważne, że ten pomyst } \\
\text { powstal” }(9,305) \\
\text { „Nasza organizacja bazuje na innowacjach. My } \\
\text { zawsze byliśmy 2-3 kroki przed konkurencja” } \\
(14,561) \\
\text { „Następna rzecz to być cały czas z przodu, jeśli } \\
\text { chodzi o innowacje” (18, 1107) }\end{array}$ \\
\hline
\end{tabular}




\begin{tabular}{|c|c|c|}
\hline & Exploitation / kontynuacja & Exploration / zmiana \\
\hline Obszar / kryterium & \multicolumn{2}{|c|}{ Badania terenowe (id respondenta, wiersz) } \\
\hline $\begin{array}{l}\text { Zasoby, umiejętności / ograniczenia } \\
\text { (Bonesso i in., 2014; Brown, } \\
\text { Eisenhardt, 1997) }\end{array}$ & $\begin{array}{l}\text { „W pierwszej kolejności patrzymy i opieramy się } \\
\text { na swoich zasobach, a jeżeli jest taka możliwość, to } \\
\text { staramy się pozyskiwać” }(15,267) \\
\text { „Ograniczamy się do rzeczy, którymi się zajmujemy. } \\
\text { Nie planujemy robić strategii, która całkowicie zmieni } \\
\text { firmę” }(13,392) \\
\text { „Musimy znać swoje ograniczenia, przeanalizować, } \\
\text { do kogo chcemy trafić, na jakim terytorium się } \\
\text { poruszamy” (3, 747) } \\
\text { „Ja wolę robić to na zasadzie miary siły na zamiary, } \\
\text { ja nie jestem Hewlett Pacard-em, Kodakiem czy inną } \\
\text { potężną firmą" }(18,572)\end{array}$ & $\begin{array}{l}\text { „Zasoby są takie, że zawsze można próbować skądś je } \\
\text { pozyskać. Jeśli się pojawia jakaś możliwość na rynku, } \\
\text { to myślimy jak ją wykorzystać. Jeśli decydujemy } \\
\text { się pójść w tę stronę, to zasoby zawsze można } \\
\text { zorganizować. To nie jest problem” (16, 202) } \\
\text { „Pomimo iż może nie wyglądamy na to, ale kilka razy } \\
\text { do roku wprowadzamy nowe rzeczy, absolutnie bez } \\
\text { jakiegokolwiek wsparcia zewnętrznego” (18, 64) } \\
\text { „(Co jest najważniejsze przy tworzeniu strategii?) } \\
\text { Odwaga. Moim największym problemem było } \\
\text { przełamanie mentalności wielu osób w firmie, które } \\
\text { miały implementować daną strategię. Brało się to ze } \\
\text { strachu, że się nie uda” (3, 706) } \\
\text { „Przy tworzeniu strategii trzeba odrzucić wszystkie } \\
\text { ograniczenia, bo wtedy się okazuje, że można wpaść } \\
\text { na takie fajne pomysty, które innym nie wpadają do } \\
\text { głowy” (16, 417) }\end{array}$ \\
\hline $\begin{array}{l}\text { Ryzyko i popełnianie błędów } \\
\text { (Lubatkin i in., 2006; March, 1991) }\end{array}$ & $\begin{array}{l}\text { „Nie inwestujemy aż tak bardzo intensywnie, że nie } \\
\text { stawiamy wszystkiego na jednej karcie” }(4,377) \\
\text { „Wybieramy te drogi, które sq akceptowalne przez } \\
\text { właścicieli, a tych dróg jest kilka do wyboru. Nie } \\
\text { podejmujemy decyzji za bardzo ryzykownych (...)” } \\
(16,185) \\
\text { „Jak ja jestem strategiem, to jestem mniejszym } \\
\text { ryzykantem. Potrafię stuchać ludzi, analizować, } \\
\text { sprawdzać i bardziej zabezpieczać. I żebym miała } \\
\text { pięć pomysłów, jak wyjść w razie problemów i jak je } \\
\text { rozwiązać. Takie zabezpieczanie się" }(8,385)\end{array}$ & $\begin{array}{l}\text { „Wybraliśmy tę, która może nie była } \\
\text { najbezpieczniejsza, ale była atrakcyjna. W najdłuższej } \\
\text { perspektywie czasowej dawała najwięcej korzyści. Jeśli } \\
\text { się powiedzie. Jest największym ryzykiem, ale daje } \\
\text { największe korzyści w sytuacji powodzenia” (7, 533) } \\
\text { „(Strateg?) No to jest taki partyzant trochę. Czyli, dla } \\
\text { mnie strategia jest zabawą, to jest taka gra” (10, 847) } \\
\text { „Jak wyjdzie, to ok, a jak nie wyjdzie, to będziemy } \\
\text { szukać innego podejścia i rozwiązań” (13, 258) } \\
\text { „Sukcesy nie ucza strategii, a porażki uczą. A porażek } \\
\text { na pewno może być mnóstwo w takim fachu, dlatego } \\
\dot{z} \text { e nie jest czymś niezwykłym, że się rozmijamy z tym, } \\
\text { jak rzeczywistość się rozwija” (17, 887) }\end{array}$ \\
\hline
\end{tabular}

Źródło: opracowanie własne (kryteria opisu w kolumnie 1 opracowano na podstawie literatury)

W tabeli 2 przedstawione zostały cytaty respondentów, pozwalające charakteryzować ich według kryterium podejścia do zmian i akceptacji niepewności oraz potwierdzające przejawy występowania obu orientacji, tj. na kontynuację i na zmianę. Obok wypowiedzi respondentów, świadczących o występowaniu jednej z badanych orientacji, tj. orientacji na kontynuację lub orientacji na zmianę, zidentyfikowano również wypowiedzi przemawiające za łączeniem obu tych cech w myśl oburęczności. Przykładowo stwierdzenie respondenta, że „strategia opiera się na tym, co obecnie posiadamy, jak i na tym, co chcemy posiadać" $(8,144)^{6}$ lub deklaracja, że „trzeba pielęgnować to, co mamy $i$ rozwijać się tam, gdzie jest coś do zrobienia" (12, 371), może świadczyć o połączeniu podejścia fit i stretch w myśleniu strategicznym.

Niektórzy respondenci uznawali tak rozumianą oburęczność za nieodzowną cechę stratega, twierdząc między innymi, że „żeby cokolwiek stworzyć, trzeba mieć wyobraźnię i logiczne myślenie” $(5,580)$, a „(dobry strateg) powinien umieć myśleć prawopółkulowo, żeby te różne scenariusze w ogóle zaistniały w jego głowie i musi umieć myśleć logicznie i przewidywać skutki własnych działań" $(10,931)$.

W podejściu oburęcznym strateg równoważy innowacyjność i rozwój $\mathrm{z}$ podnoszeniem efektywności $\mathrm{w}$ dotychczasowych działaniach. Pozornie sprzeczne priorytety realizowane są jednocześnie: „Rozwój, nowe obszary, w których moglibyśmy działać, poprawa wyników finansowych (...). To albo następni ludzie, następna hala, następne coś, albo rozwój w sensie zwiększania przychodów (...). Zupetnie nowego cos' $(1,297)$.

\section{Dyskusja}

U zyskane wyniki badań stanowią oryginalne spojrzenie na sposoby myślenia strategicznego, w tym na podejście strategów do zmian i rozwoju organizacji. Odniesienie tych wyników badań eksploracyjnych do innych rezultatów badań jest utrudnione przynajmniej z kilku powodów. Po pierwsze, w literaturze przedmiotu brakuje publikacji z wynikami badań nad cechami różnicującymi strategów, gdyż, jak sygnalizowano, większość autorów skupia się na identyfikacji cech wspólnych strategów i poszukiwaniu uniwersalnych zasad tworzenia skutecznych strategii (Yoffie, Cusumano, 2015). Podejścia ukazujące różnice i próby identyfikacji typów strategów stanowią rzadkość i są to $\mathrm{z}$ reguły opracowania z pogranicza opracowań naukowych i popularyzatorskich (Horvath, 2009; Olson, Simerson, 2015). Po drugie, dostępne analizy i opisy mają charakter fragmentaryczny, a same badania są silnie osadzone w kontekście sytuacyjnym, tj. konkretnych wydarzeń, zmian strategicznych, przełomów itd. 
Można skonstatować, że przedstawiony w artykule wymiar dotyczący podejścia do zmian i akceptacji niepewności otoczenia, jawi się jako jeden z elementów różnicujących myślicieli strategicznych. Różnice te zidentyfikowano i potwierdzono w przeprowadzonych badaniach terenowych, ale znajdują one również potwierdzenie w przeprowadzonych przez zespół badaniach biograficznych. Można na tej podstawie skonkludować, że podeście do rozwoju i zmian stanowi jeden z kluczowych wymiarów typologii myślicieli strategicznych.

Warto podkreślić pewne wyzwania metodyczne stojące przed autorami oraz wątpliwości związane z uzyskanymi wynikami badań. Jedno $\mathrm{z}$ nich dotyczy sposobu ujęcia i pomiaru analizowanych cech, $\mathrm{w}$ tym przedstawionego w artykule podejścia do zmian. Niektórzy autorzy traktują bowiem poszczególne cechy jako dychotomiczne (Liedtka, 1998), co wskazuje na klasyfikację badanych jednostek pod względem występowania danych cech na zasadzie binarnej (ciągłość albo zmiana). Inni traktują je w kategoriach przeciwnych krańców kontinuum z możliwością osiągania stanów pośrednich (Olson, Simerson, 2015), co wskazuje na możliwość wykorzystania dwukierunkowej skali ciągłej (ciągłość - zmiana). W końcu niektórzy badacze sugerują możliwość połączenia tych przeciwieństw, lokując się w nurcie dialektyki, łączenia paradoksów czy oburęczności (ambidexterity) (Bonesso i in., 2014; Lubatkin i in., 2006; Sage i in., 2010; Sushil, 2012). To ostatnie podejście pozwoliłoby na jednoczesne wykorzystanie dwóch niezależnych skal do pomiaru ich natężenia obu orientacji (ciągłość i zmiana).

Interesującym aspektem, jaki wyłonił się w badaniach jakościowych, jest dopasowanie pomiędzy sposobem myślenia a realizowaną strategią organizacji. Brak takiego dopasowania może prowadzić do napięć (tensions), a w konsekwencji powodować niezadowolenie i frustrację stratega. Sytuacja taka ma na przykład miejsce wtedy, gdy strateg o stylu myślenia explorera zmuszony jest przez warunki rynkowe lub presję właścicielską do realizowania zachowawczej strategii eksploatacji.

Dodatkowo, czynnikiem, na który warto zwrócić uwage przy interpretacji wyników badań, jest kontekst sytuacyjny i czasowy prowadzonych badań. We wszystkich przeprowadzonych wywiadach mocno wyłaniał się bowiem brak przychylności otoczenia i niekorzystne warunki do prowadzenia biznesu, wynikające między innymi z dużej niepewności otoczenia prawno-politycznego (niepewne regulacje, zmiany podatkowe itd.), złożonej sytuacji makroekonomicznej (wskazywana groźba spowolnienia gospodarczego lub widmo kryzysu), a także trudności z pozyskaniem odpowiednich pracowników i zmian w kosztach pracy. Przedstawione uwarunkowania mogą w sposób istotny wpływać na podejście do zmian i akceptację niepewności zidentyfikowane u badanych, zmieniając przejściowo ich nastawienie $\mathrm{z}$ explorera $\mathrm{w}$ kierunku kontynuacji.

\section{Podsumowanie}

M yślenie strategiczne, rozumiane jako ogół procesów poprzedzających planowanie strategiczne, ma istotny wpływ na proces tworzenia strategii, jej kształt i uzy- skiwane w wyniku jej realizacji efekty. W opracowaniu przedstawiono wyniki badań nad wybranymi cechami różnicującymi myślicieli strategicznych, koncentrując się na podejściu do zmian i akceptacji niepewności otoczenia. Samo poszukiwanie różnic w myśleniu strategicznym można uznać za oryginalne i rzucające nowe światło na badania nad uwarunkowaniami strategii, co stanowi wkład do nauk o zarządzaniu. W badaniach potwierdzono również kluczową rolę strategów w procesie formułowania i realizacji strategii, ukazując wpływ indywidualnych postaw i predyspozycji intelektualnych na kierunki rozwoju i zachowania strategiczne organizacji. Uzyskane wyniki badań stanowią asumpt do dalszych poszukiwań z wykorzystaniem podejścia ilościowego, a następnie porządkowania i typologizowania strategów na podstawie wyników uzyskanych we wszystkich etapach procesu badawczego.

Wyniki prowadzonych badań pozwalają na uporządkowanie i wzbogacenie wiedzy z zakresu zarządzania strategicznego, szczególnie w obszarze poszukiwania czynników kształtujących strategię organizacji i wyjaśniania różnic $\mathrm{w}$ zachowaniach strategicznych organizacji. Wyniki i wnioski z badań mają również wymiar aplikacyjny dla praktyki zarządzania. Znajomość stylów myślenia strategicznego, w tym podejścia do zmian i akceptacji niepewności otoczenia, nie tylko ułatwia proces formułowania strategii, ale wspomaga dobór kadr menedżerskich i umożliwia zapewnienie zróżnicowania punktów widzenia w pracach zespołowych nad strategią. Wyniki badań mogą być także wykorzystane w procesie kształcenia przyszłych menedżerów, ukazując różnorodność stylów myślenia strategicznego i możliwości ich zastosowania.

Autorzy opracowania mają świadomość istnienia ograniczeń przeprowadzonych badań na obecnym ich etapie realizacji, tj. badań terenowych. Wynikają one m.in. $\mathrm{z}$ jakościowego podejścia i związanej z tym niemożności generalizacji wyników. Warto jednak podkreślić, że przedstawione etapy badań traktować należy jako wstępne, zorientowane na eksplorację nowego pola badawczego.

Jednocześnie warto zauważyć, że przeprowadzone badania ujawniły nowe interesujące obszary i kierunki badań, związane między innymi z sygnalizowanymi napięciami pomiędzy nastawieniem stratega a faktycznie realizowaną strategią organizacji, a także identyfikacją i badaniem czynników i zmiennych kształtujących nastawienie i cechy myślicieli strategicznych, związanych zarówno ze środowiskiem, np. z sytuacją makroekonomiczną, cyklem życia organizacji i sektora, turbulencją czy natężeniem konkurencji, jak i z osobą stratega, tj. kierunkiem jego wykształcenia, płcią, doświadczeniem czy poziomem optymizmu.

\author{
dr hab. Janusz M. Lichtarski \\ Uniwersytet Ekonomiczny we Wrocławiu \\ Wydział Zarządzania \\ ORCID: 0000-0003-2077-6124 \\ e-mail: janusz.lichtarski@ue.wroc.pl
}




\section{dr hab. Anna Witek-Crabb \\ Uniwersytet Ekonomiczny we Wrocławiu \\ Wydział Zarządzania \\ ORCID: 0000-0003-2801-5952 \\ e-mail: anna.witek-crabb@ue.wroc.pl}

\author{
dr hab. Katarzyna Piórkowska \\ Uniwersytet Ekonomiczny we Wrocławiu \\ Wydział Zarządzania \\ ORCID: 0000-0001-5880-136X \\ e-mail: katarzyna.piorkowska@ue.wroc.pl
}

\section{dr Rafał Trzaska \\ Uniwersytet Ekonomiczny we Wrocławiu \\ Wydział Zarządzania \\ ORCID: 0000-0003-0261-7496 \\ e-mail: rafal.trzaska@ue.wroc.pl}

\section{mgr Maciej Wilczyński \\ Uniwersytet Ekonomiczny we Wrocławiu \\ Wydział Zarządzania \\ ORCID: 0000-0001-5030-4406 \\ e-mail: maciej.wilczynski@ue.wroc.pl}

\section{dr Sylwia Wrona \\ Uniwersytet Ekonomiczny we Wrocławiu \\ Wydział Zarządzania \\ ORCID: 0000-0001-6326-8395 \\ e-mail: sylwia.wrona@ue.wroc.pl}

\section{Przypisy}

1) Prezentowany projekt badawczy finansowany jest $\mathrm{w}$ ramach programu Ministra Nauki i Szkolnictwa Wyższego pod nazwą „Regionalna Inicjatywa Doskonałości” w latach 2019-2022 (nr proj. 15/RID/2018/19, kwota finansowania 10721 040,00 PLN).

2) Strateg i myśliciel strategiczny to pojęcia używane przez autorów zamiennie, odnoszące się do pojęcia strategic thinker, gdyż dosłowne jego tłumaczenie, jako myśliciel strategiczny, $\mathrm{w}$ języku polskim nie oddaje znaczenia terminu oryginalnego i bliższe jest mu określenie strateg.

3) Dodatkowo, do potwierdzenia i ilustracji wyłonionych na bazie badań literaturowych cech różnicujących myślicieli strategicznych jako metodę uzupełniającą wykorzystano studia biograficzne. Wyniki badań biograficznych nad cechami myślicieli strategicznych podjętych przez autorów prezentuje artykuł J. Lichtarskiego i innych (2020).

4) Wywiady prowadzone były na podstawie opracowanego przez autorów scenariusza wywiadu składającego się z wprowadzenia i sześciu części, zawierających łącznie 53 pytania otwarte.

5) Rekomendowane bazy to Diamenty Forbesa, Gazele Biznesu itp.
6) $\mathrm{W}$ nawiasach podano odpowiednio (numer respondenta, numer wiersza w transkrypcji wywiadu).

7) $\mathrm{W}$ nawiasach podano odpowiednio (numer respondenta, numer wiersza w transkrypcji wywiadu).

\section{Bibliografia}

[1] Adair J. (2005), How to Grow Leaders: The Seven Key Principles of Effective Leadership Development, Kogan Page, London.

[2] Amitabh M., Sahay A. (2007), Strategic Thinking: Is Leadership the Missing Link, http://www.iitk.ac.in/infocell/announce/convention/papers/Strategy-01-ManuAmitabhfinal. pdf, access date: 3.01.2020.

[3] Benner M.J., Tushman M.L. (2003), Exploration, Exploitation, and Process Management: The Productivity Dilemma Revisited, „Academy of Management Review”, Vol. 28, pp. 238-256.

[4] Bonesso S., Gerli F., Scapolan A. (2014), The Individual Side of Ambidexterity: Do Individuals' Perceptions Match Actual Behaviors in Reconciling the Exploration and Exploitation Trade-off? „European Management Journal”, Vol. 32, No. 3, pp. 392-405.

[5] Bonn I. (2005), Improving Strategic Thinking: A Multilevel Approach, „Leadership \& Organization Development Journal", Vol. 26, No. 5, pp. 336-354.

[6] Brown S.L., Eisenhardt K.M. (1997), The Art of Continuous Change: Linking Complexity Theory and Time-Paced Evolution in Relentlessly Shifting Organizations, „Administrative Science Quarterly”, Vol. 42, No. 1, pp. 1-34.

[7] Creswell J.W., Zhang W. (2009), The Application of Mixed Methods Designs to Trauma Research, "Journal of Traumatic Stress", Vol. 22, No. 6, pp. 612-621.

[8] Crouch A. (1998), Reframing the Strategic Problem: An Accommodation of Harmony and Belligerence in Strategic Management, „Journal of Business Research”, Vol. 41, No. 1, pp. 3-13.

[9] Czakon W. (2011), Metodyka systematycznego przeglądu literatury, „Przegląd Organizacji”, Nr 3, s. 57-61

[10] Dhir S., Dhir S., Samanta P. (2018), Defining and Developing a Scale to Measure Strategic Thinking, „Foresight”, Vol. 20, No. 3, pp. 271-288.

[11] Eisenhardt K.M. (1990), Speed and Strategic Choice: How Managers Accelerate Decision Making, „California Management Review”, Vol. 32, No. 3, pp. 39-54.

[12] Finkelstein S., Whitehead J., Campbell A. (2009), Think Again: Why Good Leaders Make Bad Decisions and How to Keep it From Happening to You, Harvard Business Press, Boston.

[13] Godet M. (2010), Future Memories, „Technological Forecasting and Social Change", Vol. 77, No. 9, pp. 1457-1463.

[14] Goldman E.F., Schlumpf K.S., Scott A.R. (2017), Combining Practice and Theory to Assess Strategic Thinking, „Journal of Strategy and Management", Vol. 10, No. 4, pp. 488-504.

[15] Goldman E.F., Scott A.R., Follman J.M. (2015), Organizational Practices to Develop Strategic Thinking, ,Journal of Strategy and Management", Vol. 8, No. 2, pp. 155-175.

[16] Graetz F. (2002), Strategic Thinking versus Strategic Planning: Towards Understanding the Complementarities, „Management Decision", Vol. 40, No. 5, pp. 456-462. 
[17] Hamel G., Prahalad C.K. (1993), Strategy as Stretch and Leverage, „Harvard Business Review”, Vol. 71, No. 2, pp. 75-84.

[18] Hanford P. (1995), Developing Director and Executive Competencies in Strategic Thinking, [in:] B. Garratt (ed.), Developing Strategic Thought: Reinventing the Art of Direction-Giving, McGraw-Hill, London, pp. 157-186.

[19] Haycock K., Cheadle A., Bluestone K.S. (2012), Strategic Thinking Lessons for Leadership from the Literature, „Library Leadership and Management", Vol. 26, No. 3/4, pp. 1-23.

[20] He Z., Wong P. (2004), Exploration vs. Exploitation: An Empirical Test of the Ambidexterity Hypothesis, „Organization Science", Vol. 15, No. 4, pp. 481-494.

[21] Heracleous L. (1998), Strategic Thinking or Strategic Planning? „Long Range Planning”, Vol. 31, No. 3, pp. 481-487.

[22] Hitt M.A., Ireland R.D., Sirmon D.G., Trahms C.A. (2011), Strategic Entrepreneurship: Creating Value for Individuals, Organizations, and Society, „Academy of Management Perspectives", Vol. 25, No. 2, pp. 57-75.

[23] Hodgkinson G.P., Sparrow P.R. (2002), The Competent Organization: A Psychological Analysis of the Strategic Management Process, Open University Press, Buckingham.

[24] Holland J.H. (1975), Adaptation in Natural and Artificial Systems, University of Michigan Press, Ann Arbor.

[25] Horowitz B. (2014), The Hard Thing about Hard Things: Building a Business when There Are no Easy Answers, Harper Business, New York.

[26] Horvath R. (2009), Deep Dive: The Proven Method for Building Strategy, Focusing your Resources, and Taking Smart Actions, Greenleaf Book Group Press, Austin.

[27] Ireland R.D., Hitt M.A., Sirmon D.G. (2003), A Model of Strategic Entrepreneurship: The Construct and its Dimensions, „Journal of Management”, Vol. 29, No. 6, pp. 963-989.

[28] Johnson G. (2007), Ritualizing Strategic Thinking: The Effectiveness of the Strategic Away Day, „Strategic Direction”, Vol. 24, No. 1, pp. 3-5.

[29] Kuran T. (1988), The Tenacious Past: Theories of Personal and Collective Conservatism, „Journal of Economic Behavior and Organization", Vol. 10, pp. 143-171.

[30] Lichtarski J.M., Piórkowska K., Wilczyński M., Witek-Crabb A., Wrona S. (2020), Strategiczni myśliciele $w$ świetle przegladu literatury i studiów biograficznych, [w:] Zarzadzanie strategiczne $w$ dobie cyfrowej gospodarki sieciowej, Wydawnictwo Uniwersytetu Łódzkiego, Łódź (w przygotowaniu).

[31] Liedtka J.M. (1998), Strategic Thinking: Can It Be Taught? „Long Range Planning”, Vol. 31, No. 1, pp. 120-129.

[32] Linnenluecke M.K., Marrone M., Singh A.K. (2020), Conducting Systematic Literature Reviews and Bibliometric Analyses, „Australian Journal of Management”, Vol. 45, No. 2, pp. 175-194.

[33] Lubatkin M.H., Simsek Z., Ling Y., Veiga J.F. (2006), Ambidexterity and Performance in Small-to medium-sized Firms: The Pivotal Role of Top Management Team Behavioral Integration, „Journal of Management”, Vol. 32, No. 5, pp. 646-672.

[34] March J. (1991), Exploration and Exploitation in Organizational Learning, „Organization Science”, Vol. 2, No. 1, pp. 71-87.

[35] Mintzberg H. (1994), The Rise and Fall of Strategic Planning, Hertfordshire, Free Press and Prentice Hall International.

[36] Muriithi S.M., Louw L., Radloff S.E. (2018), The Relationship Between Strategic Thinking and Leadership Effectiveness in Kenyan Indigenous Banks, „South Africa Journal of Economic and Management Sciences", Vol. 21, No. 1, pp. 1-11.

[37] Nonaka I. (1994), A Dynamic Theory of Organizational Knowledge Creation, „Organization Science”, Vol. 5, No. 1, pp. 14-37.

[38] Olson A.K., Simerson B.K. (2015), Leading with Strategic Thinking: Four Ways Effective Leaders Gain Insight, Drive Change, and Get Results, John Wiley \& Sons, Hoboken.

[39] Porter M.E. (2008), On Competition, Harvard Business Press, Boston.

[40] Raisch S., Birkinshaw J. (2008), Organizational Ambidexterity: Antecedents, Outcomes, and Moderators, „Journal of Management", Vol. 34, No. 3, pp. 375-409.

[41] Sage D., Dainty A., Brookes N. (2010), A Consideration of Reflexive Practice within the Critical Projects Movement, „International Journal of Project Management”, Vol. 28, No. 6, pp. 539-546.

[42] Schumpeter J.A. (1934), The Theory of Economic Development, Harvard University Press, Cambridge.

[43] Siren C.A., Kohtamäki M., Kuckertz A. (2012), Exploration and Exploitation Strategies, Profit Performance, and the Mediating Role of Strategic Learning: Escaping the Exploitation Trap, ,Strategic Entrepreneurship Journal”, Vol. 6, No. 1, pp. $18-41$.

[44] Steptoe-Warren G., Howat D., Hume I. (2011), Strategic Thinking and Decision Making: Literature Review, „Journal of Strategy and Management", Vol. 4, No. 3, pp. 238-250.

[45] Sushil (2012), Flowing Stream Strategy: Managing Confluence of Continuity and Change, ,Journal of Enterprise Transformation", Vol. 2, No. 1, pp. 26-49.

[46] Yoffie D.B., Cusumano M.A. (2015), Strategy Rules: Five Timeless Lessons from Bill Gates, Andy Grove, and Steve Jobs, Harper Business, New York.

\section{Continuity and Change in Strategic Thinking Patterns: Results of Empirical Studies}

\section{Summary}

The goal of the paper is to present the literature and empirical findings on continuity and change in strategic thinking patterns. Attitude towards change and the perception of environmental uncertainty emerged as one of the most interesting differences in strategic thinking styles. The conceptualisations of strategic thinking and identified features of strategic thinkers, both common features, and differentiating ones (e.g. the approach to change and uncertainty) are based on a systematic-critical literature review. The empirical study is based on the qualitative approach with individual in-depth semi-structured interviews as the main research method. The findings show that focus on continuity or change is one of the features that differentiate strategic thinkers' mindset.

\section{Keywords}

strategic thinking, strategic thinkers, differentiating features, qualitative studies 